\title{
Association of Liver Transaminase Levels and Long-Term Blood Pressure Variability in Military Young Males: The CHIEF Study
}

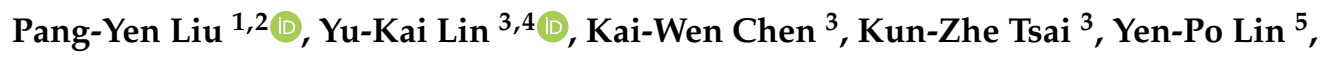 \\ Eiki Takimoto ${ }^{1}$ and Gen-Min Lin ${ }^{2,3,6, * \mathbb{D}}$ \\ 1 Department of Cardiovascular Medicine, School of Medicine, University of Tokyo, Tokyo 113-0033, Japan; \\ liupydr@gmail.com (P.-Y.L.); etakimo1@jhmi.edu (E.T.) \\ 2 Department of Internal Medicine, Tri-Service General Hospital and National Defense Medical Center, \\ Taipei 114, Taiwan \\ 3 Department of Medicine, Hualien Armed Forces General Hospital, Hualien 971, Taiwan; \\ yukai0907@ndmctsgh.edu.tw (Y.-K.L.); az0127@gmail.com (K.-W.C.); \\ stupidgrandpa@yahoo.com.tw (K.-Z.T.) \\ 4 Department of Neurology, Tri-Service General Hospital, National Defense Medical Center, Taipei 114, Taiwan \\ 5 Department of Critical Care Medicine, Taipei Tzu-Chi General Hospital, New Taipei City 231, Taiwan; \\ b101093018@tmu.edu.tw \\ 6 Department of Preventive Medicine, Northwestern University Feinberg School of Medicine, \\ Chicago, IL 60611, USA \\ * Correspondence: farmer507@yahoo.com.tw or gen-min.lin@northwestern.edu; Tel.: +886-3826-0601; \\ Fax: +886-3826-1370
}

Received: 23 June 2020; Accepted: 19 August 2020; Published: 21 August 2020

\begin{abstract}
Background: An inverse relationship of serum liver transaminases and mortality might be due to better blood pressure control in hypertensive patients. Whether it holds true regarding such an association for long-term blood pressure variability (BPV) in those without antihypertensive therapy is unclear. Methods: A population of 1112 military males without antihypertensive medications, aged 32 years, was collected from a retrospective longitudinal study in Taiwan. Serum liver aspartate and alanine transaminase (AST and ALT) levels were obtained from a $12 \mathrm{~h}$-fast blood sample of each participant. BPV was assessed by standard deviation (SD) and average real variability (ARV) of systolic and diastolic blood pressure (SBP and DBP), respectively across 4 visits during the study period (2012-2014, 2014-2015, 2015-2016, and 2016-2018). Multivariable linear regression analysis was utilized to determine the association adjusting for demographics, anthropometric indexes, SBP, DBP, and lipid profiles. Results: In the unadjusted model, ALT was significantly and positively correlated with $\mathrm{SD}_{\mathrm{DBP}}$ and $\mathrm{ARV}_{\mathrm{DBP}}(\beta$ (standard errors) $=0.36(0.16)$ and $0.24(0.12)$, respectively), and so was AST ( $\beta=0.19(0.08)$ and $0.14(0.06)$, respectively). All the associations were insignificant with adjustments. However, ALT was significantly and negatively correlated with $\mathrm{SD}_{\mathrm{SBP}}$ and $\mathrm{ARV}_{\mathrm{SBP}}$ $(\beta=-0.35(0.14)$ and $-0.25(0.11)$, respectively) and so was AST $(\beta=-0.14(0.07)$ and $-0.12(0.06)$, respectively) with adjustments. Conclusion: Our findings suggested that serum liver transaminases were negatively correlated with long-term systolic BPV in young male adults without antihypertensive therapy, and the clinical relevance needs further investigations.
\end{abstract}

Keywords: alanine transaminase; aspartate transaminase; blood pressure variability; young males

\section{Introduction}

Several hepatobiliary biomarkers have been reported with an association with cardiovascular disease (CVD), disability, and all-cause deaths [1-8]. Numerous population-based reports [1-4] 
and a meta-analysis [5] consistently showed that people who had elevated serum concentrations of gamma-glutamyl transferase (GGT) or alkaline phosphate (ALP) had higher risk of CVD and all-cause deaths. Potential mechanisms underlying the relationship between elevated GGT and increased risk of CVD have been proposed. GGT has proinflammatory and pro-oxidant properties, possibly promoting the atherosclerotic process [9]. In addition, GGT is directly involved in atheromatous plaque formation as well [10]. With regard to ALP, it is proinflammatory, and can increase bone metabolism which contributes to vascular calcification, and impair vascular homoeostasis, leading to occurrence of CVD and related deaths $[7,8]$.

In contrast, some hepatobiliary biomarkers have been revealed with beneficial effect or no influence on the cardiovascular system [3,11-15]. To our knowledge, bilirubin is a potent antioxidant and can suppress the oxidation of low-density lipoprotein cholesterol in humans [11,12]. In many population-based studies, serum bilirubin concentrations have been associated with lower risk of incident hypertension, coronary heart disease, and deaths [13-15]. However, regarding serum alanine transaminase (ALT) and aspartate transaminase (AST), the most two commonly used biomarkers for assessing hepatic injury in clinical practice, the associations with risk of CVD and deaths were inconsistently found higher, lower, or neutral in the general population [1,3-6].

Elevated serum liver transaminase concentrations are prevalent in people with viral hepatitis, toxin exposure such as alcohol intake, or nonalcoholic fatty liver disease [16-18]. Except chronic viral hepatitis [19], most of these risk factors are highly related to metabolic abnormalities, such as obesity, dyslipidemia, and prediabetes and prehypertension [20,21]. It remains unclear why some studies demonstrated that those with higher serum liver transaminases had lower risk of CVD or deaths, whereas others showed inverse results. Blood pressure variability (BPV), which has been associated with incidence of CVD, is classified according to the time-frame as short-term fluctuations of blood pressure within a 24-h period (beat-to-beat, minute-to-minute, hour-to-hour, and day-to-night changes, and long-term fluctuations over more-prolonged periods of time (days, weeks, months, and years) [22]. In a previous study [23], among hypertensive patients on antihypertensive treatment, higher serum ALT was associated with better long-term blood pressure control, explaining for the reduced CVD mortality risk. It is possible that serum liver transaminase may affect long-term variation of blood pressure in the general population. Therefore, we examined the association of serum AST and ALT with long-term blood BPV in a cohort of military young males.

\section{Materials and Methods}

\subsection{Study Population}

A cohort of 1112 healthy military males, averaged 32.2 years of age (18-40 years) and without taking any antihypertensive therapy, was retrospectively collected from the cardiorespiratory fitness and hospitalization events in armed forces (CHIEF) study in eastern Taiwan for the analysis [24]. All participants received a comprehensive health examination for requiring information of demographic data, past medical history of chronic viral hepatitis B or C, and tobacco smoking status (current vs. former and never), alcohol consumption status (current vs. former and never) and physical activity. A physical examination and blood biochemical tests were performed every two years from 2012 to 2018 (2012-2014, 2014-2015, 2015-2016, and 2016-2018) in the Hualien Armed Forces General Hospital.

\subsection{Measurements of Anthropometric and Biochemical Blood Tests}

Anthropometric measurements of body height and weight of each participant were performed in a standing position. Body mass index was defined as a ratio of body weight $(\mathrm{kg})$ divided by body height squared $\left(\mathrm{m}^{2}\right)$. Waist circumference was measured midway between the lower rib margin and iliac crest at standing position. Abdominal obesity was defined as waist circumference $\geq 90 \mathrm{~cm}$ for male adults. Blood biochemical tests for concentrations of triglycerides, total cholesterol, high-density lipoprotein, fasting glucose, and AST and ALT were enzymatically measured on an auto analyzer 
(AU640, Olympus, Kobe, Japan). All blood samples were collected by several experienced technicians at the same blood drawing station after an overnight 12-h fast for the participants [25-30].

\subsection{Measurements of Long-Term BPV}

Theophylline or caffeine-containing materials were forbidden for a 12-h fast of each participant before hospital visit. Measurements of systolic and diastolic blood pressure (SBP and DBP, respectively) of each participant was performed once over the right upper arm in a sitting position after a rest for at least $15 \mathrm{~min}$, by a FT-201 automated blood pressure monitor (Parama-Tech Co Ltd., Fukuoka, Japan) at each visit $[31,32]$. Long-term BPV was assessed by standard deviation $\left(\mathrm{SD}_{\mathrm{SBP}}\right.$ and $\left.\mathrm{SD}_{\mathrm{DBP}}\right)$ and average real variability $\left(A R V_{S B P}\right.$ and $\left.A R V_{D B P}\right)$ across 4 visits in the study period (2012-2018). $\mathrm{SD}_{\mathrm{SBP}}$ and $\mathrm{ARV}_{\mathrm{SBP}}$ were respectively represented by dotted and solid lines in Figure 1. ARV is an average of the sum of absolute differences between successive blood pressure measurements, and it takes the order of measurements into account $(|\Delta 1|+|\Delta 2|+|\Delta 3|) / 3)[24,33,34]$.

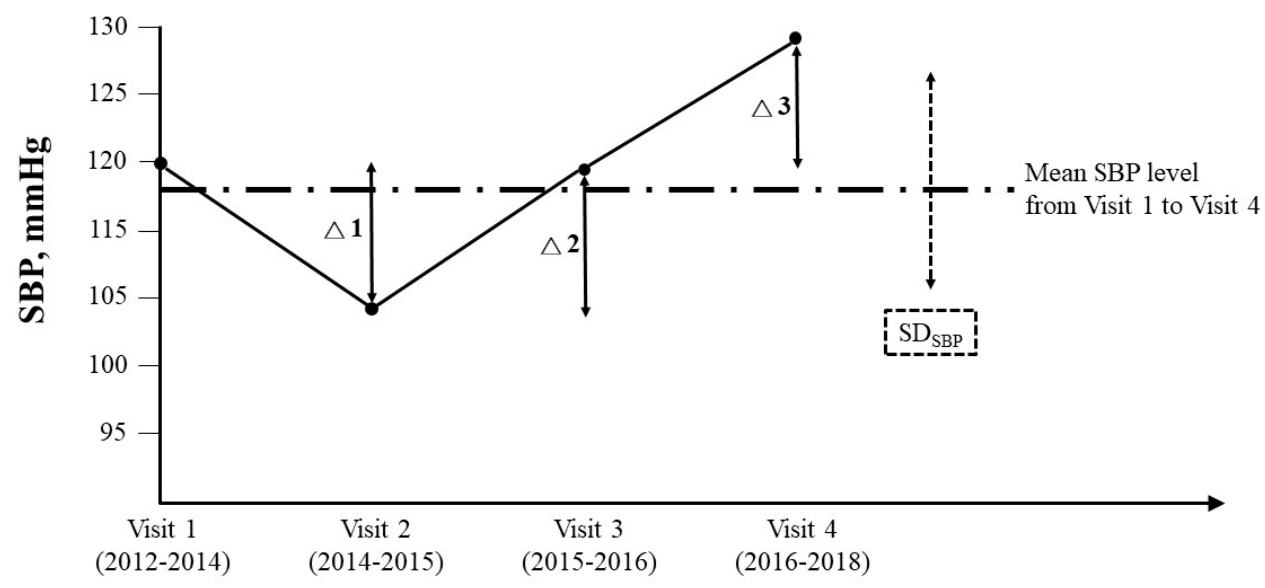

Figure 1. Long-term blood pressure variability (BPV) was assessed by standard deviation and average real variability across 4 visits in the study period (2012-2018). Standard deviation $(\mathrm{SD})_{\mathrm{SBP}}$ and average real variability $(\mathrm{ARV})_{\mathrm{SBP}}$ were respectively illustrated by dotted and solid lines. $\mathrm{ARV}_{\mathrm{SBP}}$ is an average of absolute differences between successive systolic blood pressure measurements, and it takes the order of measurements into account $(|\Delta 1|+|\Delta 2|+|\Delta 3|) / 3)$.

\subsection{Statistical Analysis}

The characteristics of participants who had serum ALT $\geq 30 \mathrm{U} / \mathrm{L}$, the upper limit of normal levels of serum ALT [35], $(n=254)$ and those who had serum ALT $<30 \mathrm{U} / \mathrm{L}(\mathrm{n}=858)$ were expressed as mean $\pm \mathrm{SD}$ and compared by two-sample t-test for continuous data, and presented as numbers (\%) and compared by chi-square test for categorical data. In addition, the characteristics of participants who had serum AST $\geq 30 \mathrm{U} / \mathrm{L}$, the upper limit of normal levels of serum AST [35], $(\mathrm{n}=118)$ and those who had serum AST $<30 \mathrm{U} / \mathrm{L}(\mathrm{n}=994)$ were compared in the same manner. In order to reveal the distribution of BPV for all study participants, the range of each BPV index was divided by quantile. Differences in serum liver transaminase levels among the quantile groups were assessed using analysis of covariance (ANCOVA) with adjustment for the baseline SBP and DBP levels. Unadjusted and multivariable adjusted linear regression were used to determine the relationship of serum AST and ALT levels with long-term BPV in the overall cohort and those without current alcohol intake $(\mathrm{n}=681)$. In model 1, the baseline SBP and DBP levels (2012-2014) were initially adjusted. In model 2, age, body mass index, abdominal obesity, smoking status, alcohol intake status, serum triglycerides, fasting glucose, total cholesterol, high-density lipoprotein cholesterol, and physical activity (average weekly exercise frequency in past 3 months) were additionally adjusted. This study was approved by the Institutional Review Board of the Mennonite Christian Hospital (No. 16-05-008) in Hualien, Taiwan and written 
informed consent was obtained from all participants. A $p$-value $<0.05$ was considered significant. SAS statistical software (SAS version 9.4; SAS Institute, Cary, NC, USA) was used for all statistical analyses.

\section{Results}

Table 1 reveals the baseline characteristics of the study participants (2012-2014). The males with higher serum ALT had similar heart rate, physical activity, and prevalence of current smokers and current alcohol consumers compared with those with lower serum ALT. However, the males with higher serum ALT had greater age, SBP, DBP, body mass index, waist circumference, fasting glucose, serum triglycerides, total cholesterol and serum AST, and lower high-density lipoprotein cholesterol. There were no participants reported with chronic viral hepatitis. Supplementary Table S1 shows similar patterns for the baseline profiles of the study participants classified by serum AST.

Table 1. Clinical characteristics of the study cohort.

\begin{tabular}{|c|c|c|c|}
\hline Variables & $\mathrm{ALT} \geq 30 \mathrm{U} / \mathrm{L}(\mathrm{N}=254)$ & ALT < $30 \mathrm{U} / \mathrm{L}(\mathrm{N}=858)$ & $p$-Value \\
\hline Age (yr) & $32.71 \pm 3.74$ & $32.07 \pm 3.91$ & 0.02 \\
\hline BMI $\left(\mathrm{kg} / \mathrm{m}^{2}\right)$ & $26.81 \pm 2.48$ & $24.64 \pm 2.83$ & $<0.001$ \\
\hline Waist circumference $(\mathrm{cm})$ & $88.51 \pm 6.12$ & $83.10 \pm 7.09$ & $<0.001$ \\
\hline $\mathrm{SBP}(\mathrm{mmHg})$ & $121.31 \pm 13.40$ & $117.47 \pm 13.26$ & $<0.001$ \\
\hline DBP (mmHg) & $73.22 \pm 10.60$ & $71.12 \pm 9.89$ & 0.004 \\
\hline Heart rate (beats/minute) & $75.74 \pm 11.16$ & $74.81 \pm 10.43$ & 0.22 \\
\hline Serum triglycerides (mg/dL) & $164.01 \pm 136.37$ & $110.88 \pm 91.09$ & $<0.001$ \\
\hline FPG (mg/dL) & $96.63 \pm 16.20$ & $93.87 \pm 12.43$ & 0.004 \\
\hline Total cholesterol (mg/dL) & $191.93 \pm 37.36$ & $176.67 \pm 30.43$ & $<0.001$ \\
\hline HDL-C (mg/dL) & $45.82 \pm 9.69$ & $48.66 \pm 9.92$ & $<0.001$ \\
\hline $\begin{array}{l}\text { ALT (U/L) } \\
\text { (Minimum-Maximum) }\end{array}$ & $\begin{array}{l}48.04 \pm 24.40 \\
(30-213)\end{array}$ & $\begin{array}{l}17.55 \pm 5.74 \\
\quad(5-29)\end{array}$ & $<0.001$ \\
\hline $\begin{array}{l}\text { AST (U/L) } \\
\text { (Minimum-Maximum) }\end{array}$ & $\begin{array}{c}30.50 \pm 13.54 \\
\quad(16-124)\end{array}$ & $\begin{array}{l}18.45 \pm 5.03 \\
(10-57)\end{array}$ & $<0.001$ \\
\hline \multicolumn{4}{|l|}{ Physical activity } \\
\hline Never or occasionally & $42[16.5]$ & 143 [16.7] & 0.99 \\
\hline 1-2 times/week & $98[38.6]$ & 329 [38.3] & \\
\hline$\geq 3-5$ times/week & 114 [44.9] & $386[45.0]$ & \\
\hline Current alcohol drinker (n [\%]) & $121[47.6]$ & 396 [46.2] & 0.67 \\
\hline Current smoker (n [\%]) & $99[39.0]$ & $332[38.7]$ & 0.93 \\
\hline
\end{tabular}

Continuous variables are expressed as mean \pm standard deviation and categorical variables as number (percentage). Abbreviations: ALT, alanine aminotransferase; AST, aspartate aminotransferase; BMI, body mass index; FPG, fasting plasma glucose; HDL-C, high density lipoprotein cholesterol.

Figure 2 shows mean (95\% confidence intervals) levels of serum AST and ALT with adjustment for the baseline SBP and DBP in quantiles of $\mathrm{SD}_{\mathrm{BP}}$ and $\mathrm{ARV}_{\mathrm{BP}}$. In general, higher $\mathrm{SD}_{\mathrm{SBP}}$ and $\mathrm{ARV} \mathrm{SBP}_{\mathrm{SP}}$ were significantly associated with lower mean levels of serum AST and ALT, except a borderline significant association between $\mathrm{ARV}_{\mathrm{SBP}}$ and mean levels of serum ALT $(p=0.06)$. In contrast, there were no significant relationships of diastolic BPV indexes with mean levels of serum AST and ALT with adjustment.

The results of multivariable linear regression analysis for the overall cohort are revealed in Table 2. In the unadjusted model, serum ALT and AST were positively and significantly correlated with ARV DBP ( $\beta$ and standard errors (SE) $=0.24$ (0.12) and $0.14(0.06)$, respectively) and $\operatorname{SD}_{\mathrm{DBP}}(\beta=0.36(0.16)$ and $0.19(0.08)$, respectively). However, serum ALT and AST were negatively and borderline significantly correlated with $\operatorname{ARV}_{\mathrm{SBP}}\left(\beta=-0.22(0.12)\right.$ and $-0.11(0.06)$, respectively) and $\mathrm{SD}_{\mathrm{SBP}}(\beta=-0.28(0.15)$ and -0.13 (0.08), respectively). With adjustment for the baseline SBP and DBP in model 1, the positive correlations of serum ALT and ALT with diastolic BPV indexes reduced and were insignificant, and so were in the fully adjusted model 2. On the contrary, the inverse correlations of serum ALT and AST with $\mathrm{ARV}_{\mathrm{SBP}}$ in model 1 turned to be significant, and were consistently significant in model $2(\beta=-0.25$ (0.11) and $-0.12(0.06)$, respectively). Similarly, the inverse correlations of serum ALT and AST with $\mathrm{SD}_{\text {SBP }}$ were significant in model 1 , and remained significant in model $2(\beta=-0.35(0.14)$ and -0.14 
(0.07), respectively). In Supplementary Table S2, the results of multivariable linear regression analysis for those without current alcohol intake were in line with that for the overall cohort. In model 2, serum ALT was significantly and inversely correlated with $\operatorname{ARV}_{\mathrm{SBP}}$ and $\mathrm{SD}_{\mathrm{SBP}}(\beta=-0.36(0.14)$ and -0.49 (0.19), respectively), and serum AST was borderline significantly and inversely correlated with $\mathrm{ARV}_{\mathrm{SBP}}$ and $\mathrm{SD}_{\mathrm{SBP}}(\beta=-0.13$ (0.07) and -0.17 (0.09), respectively).
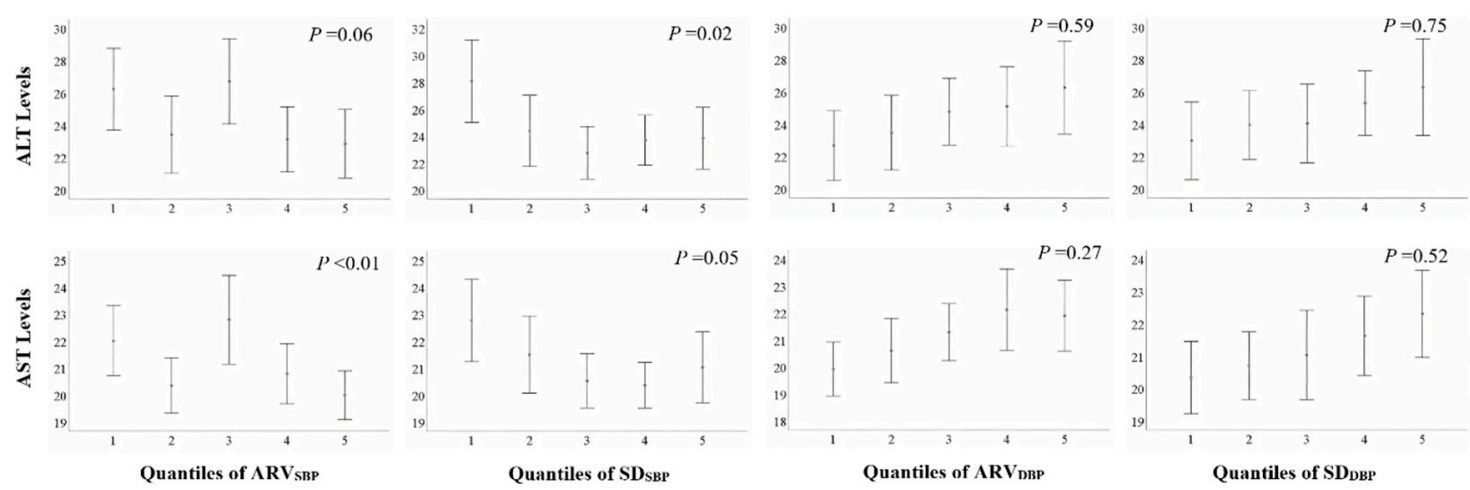

Figure 2. Serum liver transaminase levels in quantiles of average real variability $(\mathrm{ARV})_{\mathrm{BP}}$ and standard deviation $(\mathrm{SD})_{\mathrm{BP}}$. Bars represent means (95\% confidence intervals) with adjustment for systolic blood pressure (SBP) and diastolic blood pressure (DBP). $p$-values were calculated by ANCOVA.

Table 2. Association of serum alanine transaminase (ALT) and aspartate transaminase (AST) levels with long-term blood pressure variability in multivariable liner regression.

\begin{tabular}{|c|c|c|c|c|c|c|c|c|c|}
\hline \multirow{2}{*}{ BPV Indexes } & \multicolumn{3}{|c|}{ Unadjusted } & \multicolumn{3}{|c|}{ Model 1} & \multicolumn{3}{|c|}{ Model 2} \\
\hline & $\beta$ (SE) & $p$-Value & $\mathbf{R}^{2}, \%$ & $\beta$ (SE) & $p$-Value & $\mathbf{R}^{2}, \%$ & $\beta$ (SE) & $p$-Value & $\mathbf{R}^{2}, \%$ \\
\hline \multicolumn{10}{|l|}{ ALT levels } \\
\hline $\mathrm{ARV}_{\mathrm{SBP}}$ & $\begin{array}{l}-0.217 \\
(0.115)\end{array}$ & 0.05 & 0.3 & $\begin{array}{l}-0.225 \\
(0.114)\end{array}$ & 0.04 & 1.8 & $\begin{array}{l}-0.253 \\
(0.108)\end{array}$ & 0.01 & 13.7 \\
\hline $\mathrm{ARV}_{\mathrm{DBP}}$ & $\begin{array}{c}0.240 \\
(0.122)\end{array}$ & 0.04 & 0.4 & $\begin{array}{c}0.157 \\
(0.123)\end{array}$ & 0.20 & 1.6 & $\begin{array}{c}0.087 \\
(0.116)\end{array}$ & 0.45 & 13.3 \\
\hline $\mathrm{SD}_{\mathrm{SBP}}$ & $\begin{array}{l}-0.277 \\
(0.149)\end{array}$ & 0.06 & 0.3 & $\begin{array}{l}-0.297 \\
(0.148)\end{array}$ & 0.04 & 1.8 & $\begin{array}{l}-0.345 \\
(0.140)\end{array}$ & 0.01 & 13.8 \\
\hline $\mathrm{SD}_{\mathrm{DBP}}$ & $\begin{array}{c}0.362 \\
(0.161)\end{array}$ & 0.02 & 0.5 & $\begin{array}{c}0.236 \\
(0.164)\end{array}$ & 0.15 & 1.7 & $\begin{array}{c}0.151 \\
(0.155)\end{array}$ & 0.33 & 13.4 \\
\hline \multicolumn{10}{|l|}{ AST levels } \\
\hline $\mathrm{ARV}_{\mathrm{SBP}}$ & $\begin{array}{c}-0.114 \\
(0.059)\end{array}$ & 0.05 & 0.3 & $\begin{array}{l}-0.117 \\
(0.059)\end{array}$ & 0.04 & 1.9 & $\begin{array}{l}-0.115 \\
(0.057)\end{array}$ & 0.04 & 9.2 \\
\hline$A R V_{D B P}$ & $\begin{array}{c}0.139 \\
(0.063)\end{array}$ & 0.02 & 0.4 & $\begin{array}{c}0.097 \\
(0.064)\end{array}$ & 0.12 & 1.8 & $\begin{array}{c}0.071 \\
(0.062)\end{array}$ & 0.25 & 9.0 \\
\hline $\mathrm{SD}_{\mathrm{SBP}}$ & $\begin{array}{l}-0.127 \\
(0.077)\end{array}$ & 0.09 & 0.2 & $\begin{array}{l}-0.135 \\
(0.076)\end{array}$ & 0.07 & 1.9 & $\begin{array}{l}-0.144 \\
(0.074)\end{array}$ & 0.05 & 9.2 \\
\hline $\mathrm{SD}_{\mathrm{DBP}}$ & $\begin{array}{c}0.187 \\
(0.083)\end{array}$ & 0.02 & 0.5 & $\begin{array}{c}0.123 \\
(0.085)\end{array}$ & 0.14 & 1.8 & $\begin{array}{c}0.096 \\
(0.082)\end{array}$ & 0.24 & 9.0 \\
\hline
\end{tabular}

Data are presented as $\beta$ (SE, standard errors) using Pearson's correlation coefficient for the association of serum ALT and AST levels with long-term blood pressure variability (BPV) with adjustments in Model 1: systolic blood pressure (SBP) and diastolic blood pressure (DBP) adjustments; Model 2: the covariates in Model 1, age, body mass index, waist circumference $\geq 90 \mathrm{~cm}$, serum triglycerides, total cholesterol, high-density lipoprotein, physical activity, current alcohol consumer, and current smoker.

\section{Discussion}

Our main findings were that in military young males without antihypertensive therapy, those males with elevated levels of serum ALT ( $\geq 30 \mathrm{U} / \mathrm{L})$ had higher baseline SBP and DBP compared with those with normal levels of serum ALT $(<30 \mathrm{U} / \mathrm{L})$, which were in line with the results in several previous reports [31-35]. Although there was a positive association of liver transaminase concentrations with long-term diastolic BPV, the association could be explained by the baseline SBP, DBP, and other potential covariates. In contrast, an inverse association of serum ALT and AST concentrations with long-term 
systolic BPV was present independently of the baseline blood pressure and all covariates adjustments, and was not altered in those without current alcohol intake.

To our knowledge, current evidence regarding a relationship between elevated serum ALT and higher blood pressure were observed in the general population regardless of young or old age [36-39]. However, the blood pressure association for serum AST was less than that for serum ALT, possibly due to contamination of AST in blood circulation from the sources other than liver such as muscle or gastrointestinal tracts [36,37]. In addition, consumption of alcoholic beverages has been reported as a possible confounder. Fu et al. found that alcohol intake might reduce the positive association between higher serum ALT levels within normal ranges and increased arterial stiffness and elevated blood pressure [40]. However, some studies showed that alcohol intake would not alter the positive association between serum liver transaminase levels and blood pressure in the middle- and old-aged individuals [37,41]. Whether total accumulated amount of alcohol intake may mediate the relationship has not be confirmed and needs further investigations.

With regard to the studies reporting a positive association between serum ALT and risk of mortality, the results were obtained from the studies for middle or old-aged individuals who had multiple cardiovascular risk factors and without excluding chronic viral hepatitis $[2,4,6]$. In addition, the positive relationship was mainly observed in the subgroups of those with Asian ethnicity, male sex, or those with low body mass index $[2,4,6]$. However, several studies including a meta-analysis paradoxically revealed an inverse or null association of serum ALT levels with incident CVD and related mortality in the general population $[3,5,6]$. Possible mechanisms for the inverse relationship with mortality have been proposed. First, low ALT levels might reflect a poor nutritional status and low body mass [3]. In addition, low ALT might be associated with reduced liver size and blood flow in the elderly who had lower productions of protein and greater susceptibility to toxins, possibly increasing the risk of mortality $[42,43]$.

However, it remains unclear regarding the inverse relationship between serum ALT and risk of CVD [6,22]. Though McCallum et al. have found that the inverse result might be due to higher serum ALT with better long-term blood pressure control in hypertensive patients on medical treatment [22], the biological mechanisms for the inverse association between serum ALT levels and long-term blood pressure changes are still vague [22]. The longitudinal SBP changes related to alteration in pharmaco-kinetic or pharmacodynamic parameters are likely reflected in serum ALT levels [22]. In their study, the effect of serum ALT on longitudinal SBP changes were prominent in subgroups of older ages or overweight or consumed alcohol [22]. Instead of being with multiple comorbidities, our report was the first study using healthy young male adults who did not use antihypertensive medications. It clearly clarified that the positive association between serum ALT levels and long-term diastolic BPV, a CVD risk factor, could be accounted for the baseline blood pressure levels. As was known, blood pressure levels were the major determinant of BPV and have been proposed to explain the association between BPV and CVD in some studies [44,45]. By contrast, the inverse association with long-term systolic BPV was independent of all the adjusted confounders, which was in line with the findings by McCallum et al. Although light or moderate alcohol intake may increase serum liver enzymes and reduce risk of CVD death and short-term BPV, possibly by lowering aortic stiffness [46-48], the inverse relationship of serum ALT and AST with long-term systolic BPV was also observed in participants without alcohol intake and the dose effect of alcohol consumption in active drinkers could not be assessed for lack of relevant information in this study.

There were several strengths in this study. First, the physical and laboratory examinations were all performed in a strict manner, and the whole procedures were standardly performed in the same referral military hospital. Second, since the daily lifestyle of military such as the diet intake and physical training were unified, many unmeasured factors had been controlled at baseline. By contrast, there were some limitations in this study. First, the results were merely obtained from male subjects and might not be applied to female subjects. Second, although many covariates at baseline were adjusted in the model, we could not completely avoid the possibility of existing potential confounders 
to result in a bias, such as information for the amount of weekly alcohol intake which was not available from the questionnaire. Third, although we excluded participants with chronic viral hepatitis $B$ or $C$ by a self-report, we could not guarantee the data clean despite the prevalence of chronic viral hepatitis B less than $3 \%$ in the military in Taiwan [16].

In conclusion, our findings suggested that serum ALT and AST concentrations were significantly and inversely correlated with long-term systolic BPV among healthy military young males without taking any antihypertensive medications and free of history of chronic viral hepatitis B or C, as well as in those without active alcohol intake. These novel findings might provide support for the inverse relationship of serum liver transaminases with risk of CVD and mortality found in previous studies. However, it remains unclear regarding the mechanisms of the inverse association for serum ALT and AST with long-term systolic BPV, and we require further study to determine which unmeasured bias may account for the reverse epidemiology.

Supplementary Materials: The following are available online at http://www.mdpi.com/1660-4601/17/17/6094/s1, Table S1: Clinical Characteristics of Study Cohort, Table S2: Association of Serum ALT and AST with Long-Term Blood Pressure Variability in Participants Without Current Alcohol Intake in Multivariable Liner Regression.

Author Contributions: G.-M.L. contributed to conception and design of the study, as well as acquisition and interpretation of the data; K.-Z.T. analyzed the data; K.-W.C., Y.-P.L., and Y.-K.L. collected and reviewed the data; P.-Y.L. wrote the article; E.T. made critical revisions related to important intellectual content of the article. All authors have read and agreed to the published version of the manuscript.

Funding: This study was funded by the Hualien Armed Forces General Hospital (grant number 805-C109-07).

Conflicts of Interest: All authors declare no conflict of interest.

\section{References}

1. Arndt, V.; Brenner, H.; Rothenbacher, D.; Zschenderlein, B.; Fraisse, E.; Fliedner, T.M. Elevated liver enzyme activity in construction workers: Prevalence and impact on early retirement and all-cause mortality. Int. Arch. Occup. Environ. Health 1998, 71, 405-412. [CrossRef] [PubMed]

2. Kim, H.C.; Nam, C.M.; Jee, S.H.; Han, K.H.; Oh, D.K.; Suh, I.I. Normal serum amino-transferase concentration and risk of mortality from liver diseases: Prospective cohort study. Br. Med. J. 2004, 328, 983.

3. Ford, I.; Mooijaart, S.P.; Lloyd, S.; Murray, H.M.; Westendorp, R.G.J.; de Craen, A.J.M.; Packard, C.J.; Buckley, B.; Barlow, C.; Preiss, D.; et al. The inverse relationship between alanine aminotransferase in the normal range and adverse cardiovascular and non-cardiovascular outcomes. Int. J. Epidemiol. 2011, 40, 1530-1538. [CrossRef] [PubMed]

4. Nakamura, K.; Okamura, T.; Kanda, H.; Hayakawa, T.; Okayama, A.; Ueshima, H. The value of combining serum alanine amino-transferase levels and body mass index to predict mortality and medical costs: A 10-year follow-up study of National Health Insurance in Shiga, Japan. J. Epidemiol. 2006, 16, 15-20. [CrossRef] [PubMed]

5. Ruhl, C.E.; Everhart, J.E. Elevated serum alanine aminotransferase and gamma-glutamyltransferase and mortality in the United States population. Gastroenterology 2009, 136, 477-485. [CrossRef] [PubMed]

6. Kunutsor, S.K.; Apekey, T.A.; Khan, H. Liver enzymes and risk of cardiovascular disease in the general population: A meta-analysis of prospective cohort studies. Atherosclerosis 2014, 236, 7-17. [CrossRef]

7. Tonelli, M.; Curhan, G.; Pfeffer, M.; Sacks, F.; Thadhani, R.; Melamed, M.L.; Wiebe, N.; Muntner, P. Relation between alkaline phosphatase, serum phosphate, and all-cause or cardiovascular mortality. Circulation 2009, 120, 1784e92. [CrossRef]

8. Shimizu, Y.; Imano, H.; Ohira, T.; Kitamura, A.; Kiyama, M.; Okada, T.; Ishikawa, Y.; Shimamoto, T.; Yamagishi, K.; Tanigawa, T.; et al. Alkaline phosphatase and risk of stroke among Japanese: The circulatory risk in communities study (CIRCS). J. Stroke Cerebrovasc. Dis. 2012, 22, 1046e55. [CrossRef]

9. Emdin, M.; Pompella, A.; Paolicchi, A. Gamma-glutamyltransferase, atherosclerosis, and cardiovascular disease: Triggering oxidative stress within the plaque. Circulation 2005, 112, 2078-2080. [CrossRef]

10. Franzini, M.; Corti, A.; Martinelli, B.; Corso, A.D.; Emdin, M.; Parenti, G.F.; Glauber, M.; Pompella, A.; Paolicchi, A. Gamma-glutamyltransferase activity in human atherosclerotic plaques-biochemical similarities with the circulating enzyme. Atherosclerosis 2009, 202, 119-127. [CrossRef] 
11. Yesilova, Z.; Serdar, M.; Ercin, C.N.; Gunay, A.; Kilciler, G.; Hasimi, A.; Uygun, A.; Kurt, I.; Erbil, M.K.; Dagalp, K. Decreased oxidation susceptibility of plasma low density lipoproteins in patients with Gilbert's syndrome. J. Gastroenterol. Hepatol. 2008, 23, 1556-1560. [CrossRef] [PubMed]

12. Sedlak, T.W.; Saleh, M.; Higginson, D.S.; Paul, B.D.; Juluri, K.R.; Snyder, S.H. Bilirubin and glutathione have complementary antioxidant and cytoprotective roles. Proc. Natl. Acad. Sci. USA 2009, 106, 5171-5176. [CrossRef] [PubMed]

13. Lin, J.P.; Vitek, L.; Schwertner, H.A. Serum bilirubin and genes controlling bilirubin concentrations as biomarkers for cardiovascular disease. Clin. Chem. 2010, 56, 1535-1543. [CrossRef] [PubMed]

14. Lin, J.P.; O'Donnell, C.J.; Schwaiger, J.P.; Cupples, L.A.; Lingenhel, A.; Hunt, S.C.; Yang, S.; Kronenberg, F. Association between the UGT1A1*28 allele, bilirubin levels, and coronary heart disease in the Framingham Heart Study. Circulation 2006, 114, 1476-1481. [CrossRef]

15. Horsfall, L.J.; Rait, G.; Walters, K.; Swallow, D.M.; Pereira, S.P.; Nazareth, I.; Petersen, I. Serum bilirubin and risk of respiratory disease and death. JAMA 2011, 305, 691-697. [CrossRef]

16. Chen, Y.J.; Chen, K.W.; Shih, Y.L.; Su, F.Y.; Lin, Y.P.; Meng, F.C.; Lin, F.; Yu, Y.S.; Han, C.L.; Wang, C.H.; et al. Chronic hepatitis B, nonalcoholic steatohepatitis and physical fitness of military males: CHIEF study. World J. Gastroenterol. 2017, 23, 4587-4594. [CrossRef]

17. Wang, F.; Zhang, Y.J.; Zhou, Y.; Li, Y.; Zhou, T.; Zheng, J.; Zhang, J.J.; Li, S.; Xu, D.P.; Li, H.B. Effects of beverages on alcohol metabolism: Potential health benefits and harmful impacts. Int. J. Med. Sci. 2016, 17, 354. [CrossRef]

18. Angulo, P.; Hui, J.M.; Marchesini, G.; Bugianesi, E.; George, J.; Farrell, G.C.; Enders, F.; Saksena, S.; Burt, A.D.; Bida, J.P.; et al. The NAFLD fibrosis score: A noninvasive system that identifies liver fibrosis in patients with NAFLD. Hepatology 2007, 45, 846-854. [CrossRef]

19. Razi, B.; Alizadeh, S.; Omidkhoda, A.; Imani, D.; Rezaei, R. Association of chronic hepatitis B infection with metabolic syndrome and its components: Meta-analysis of observational studies. Diabetes Metab. Syndr. 2017, 11, S939-S947. [CrossRef]

20. Perumpail, B.J.; Khan, M.A.; Yoo, E.R.; Cholankeril, G.; Kim, D.; Aijaz Ahmed, A. Clinical epidemiology and disease burden of nonalcoholic fatty liver disease. World J. Gastroenterol. 2017, 23, 8263-8276. [CrossRef]

21. Mahli, A.; Hellerbrand, C. Alcohol and obesity: A dangerous association for fatty liver disease. Dig. Dis. 2016, 34, 32-39. [CrossRef] [PubMed]

22. McCallum, L.; Panniyammakal, J.; Hastie, C.E.; Hewitt, J.; Rajan Patel, R.; Jones, G.C.; Muir, S.; Walters, M.; Sattar, N.; Dominiczak, A.F.; et al. Longitudinal blood pressure control, long-term mortality, and predictive utility of serum liver enzymes and bilirubin in hypertensive patients. Hypertension 2015, 66, 37-43. [CrossRef] [PubMed]

23. Parati, G.; Ochoa, J.E.; Lombardi, C.; Bilo, G. Assessment and management of blood-pressure variability. Nat. Rev. Cardiol. 2013, 10, 143-155. [CrossRef]

24. Lin, G.M.; Tsai, K.Z.; Lin, C.S.; Han, C.L. Physical fitness and long-term blood pressure variability of young male military personnel. Curr. Hypertens. Rev. 2019, 140, A14908. [CrossRef]

25. Lin, G.M.; Li, Y.H.; Lee, C.J.; Shiang, J.C.; Lin, K.H.; Chen, K.W.; Chen, Y.J.; Wu, C.F.; Lin, B.S.; Yu, Y.S.; et al. Rationale and design of the cardio- respiratory fitness and hospitalization events in armed forces study in Eastern Taiwan. World J. Cardiol. 2016, 8, 464-471. [CrossRef]

26. Tsai, K.Z.; Lin, J.W.; Lin, F.; Su, F.Y.; Li, Y.H.; Lin, Y.P.; Lin, Y.K.; Han, C.L.; Hsieh, C.B.; Lin, G.M. Association of betel nut chewing with exercise performance in a military male cohort: The CHIEF study. J. R. Army Med. Corps 2018, 164, 399-404. [CrossRef]

27. Tsai, K.Z.; Lai, S.W.; Hsieh, C.J.; Lin, C.S.; Lin, Y.P.; Tsai, S.C.; Chung, P.S.; Lin, Y.K.; Lin, T.C.; Ho, C.L.; et al. Association between mild anemia and physical fitness in a military male cohort: The CHIEF study. Sci. Rep. 2019, 9, 11165. [CrossRef] [PubMed]

28. Chao, W.H.; Su, F.Y.; Lin, F.; Yu, Y.S.; Lin, G.M. Association of electrocardiographic left and right ventricular hypertrophy with physical fitness of military males: The CHIEF study. Eur. J. Sport Sci. 2019, 19, 1214-1220. [CrossRef]

29. Su, F.Y.; Wang, S.H.; Lu, H.H.; Lin, G.M. Association of tobacco smoking with physical fitness of military males in taiwan: The CHIEF study. Can. Respir. J. 2020, 2020, 5968189. [CrossRef] 
30. Lu, S.C.; Liu, F.Y.; Hsieh, C.J.; Su, F.Y.; Wong, T.Y.; Tai, M.C.; Chen, J.T.; Lin, G.M. Quantitative physical fitness measures inversely associated with myopia severity in military males: The CHIEF study. Am. J. Men Health 2019, 13, 1557988319883766. [CrossRef]

31. Lin, G.M.; Lu, H.H. A 12-lead ECG-based system with physiological parameters and machine learning to identify right ventricular hypertrophy in young adults. IEEE J. Transl. Eng. Health Med. 2020, 8, 1900510. [CrossRef] [PubMed]

32. Lin, G.M.; Liu, K. An electrocardiographic system with anthropometrics via machine learning to screen left ventricular hypertrophy among young adults. IEEE J. Transl. Eng. Health Med. 2020, 8, 1800111. [CrossRef]

33. Yano, Y.; Ning, H.; Allen, N.; Reis, J.P.; Launer, L.J.; Liu, K.; Yaffe, K.; Greenland, P.; Lloyd-Jones, D.M. Long-term blood pressure variability throughout young adulthood and cognitive function in midlife: The coronary artery risk development in young adults (CARDIA) study. Hypertension 2014, 64, 983-988. [CrossRef] [PubMed]

34. Yano, Y.; Griswold, M.; Wang, W.; Greenland, P.; Lloyd-Jones, D.M.; Heiss, G.; Gottesman, R.F.; Mosley, T.H. Long-term blood pressure level and variability from midlife to later life and subsequent cognitive change: The ARIC neurocognitive study. J. Am. Heart Assoc. 2018, 7, e009578. [CrossRef] [PubMed]

35. Chen, K.W.; Meng, F.C.; Shih, Y.L.; Su, F.Y.; Lin, Y.P.; Lin, F.; Lin, J.W.; Chang, W.K.; Lee, C.J.; Li, Y.H.; et al. Sex-specific association between metabolic abnormalities and elevated alanine aminotransferase levels in a military cohort: The CHIEF study. Int. J. Environ. Res. Publ. Health 2018, 15, 545. [CrossRef]

36. Kim, H.R.; Han, M.A. Association between serum liver enzymes and metabolic syndrome in Korean adults. Int. J. Environ. Res. Publ. Health 2018, 15, 1658. [CrossRef]

37. Porter, S.A.; Pedley, A.; Massaro, J.M.; Vasan, R.S.; Hoffmann, U.; Fox, C.S. Aminotransferase levels are associated with cardiometabolic risk above and beyond visceral fat and insulin resistance: The framingham heart study. Arterioscler. Thromb. Vasc. Biol. 2013, 33, 139-146. [CrossRef]

38. Chen, S.; Guo, X.; Zhang, X.; Yu, S.; Yang, H.; Jiang, M. Association between elevated serum alanine aminotransferase and cardiometabolic risk factors in rural Chinese population: A cross-sectional study. BMC Cardiovasc. Disord. 2015, 15, 65. [CrossRef]

39. Park, H.K.; Hwang, J.S.; Moon, J.S.; Lee, J.A.; Kim, D.H.; Lim, J.S. Healthy range of serum alanine aminotransferase and its predictive power for cardiovascular risk in children and adolescents. J. Pediatr. Gastroenterol. Nutr. 2013, 56, 686-691. [CrossRef]

40. Fu, S.; Lin, Y.; Luo, L.; Ye, P. The relationship of serum alanine aminotransferase normal-range levels to arterial stiffness and metabolic syndrome in non-drinkers and drinkers: A Chinese community-based analysis. BMC Gastroenterol. 2017, 17, 49. [CrossRef]

41. Sogabe, M.; Okahisa, T.; Nakagawa, T.; Fukuno, H.; Nakasono, M.; Tomonari, T.; Tanaka, T.; Tanaka, H.; Taniguchi, T.; Muguruma, N.; et al. Influence of light alcohol consumption on lifestyle-related diseases: A predictor of fatty liver with liver enzyme elevation in Japanese females with metabolic syndrome. BMC Gastroenterol. 2016, 16, 17. [CrossRef] [PubMed]

42. Yang, M.C.; McLean, A.J.; Le Couteur,, D.G. Age-related alteration in hepatic disposition of the neurotoxin 1-methyl-4-phenyl-1,2,3,6-tetrahydropyridine and pesticides. Pharmacol. Toxicol. 2002, 90, 203-207. [CrossRef]

43. Wagenmakers, A.J. Muscle amino acid metabolism at rest and during exercise: Role in human physiology and metabolism. Exerc. Sport Sci. Rev. 1998, 26, 287-314. [CrossRef] [PubMed]

44. Verdecchia, P.; Borgioni, C.; Ciucci, A.; Gattobigio, R.; Schillaci, G.; Sacchi, N.; Santucci, A.; Santucci, C.; Reboldi, G.; Porcellati, C. Prognostic significance of blood pressure variability in essential hypertension. Blood Press. Monit. 1996, 1, 3-11. [CrossRef]

45. Gómez-Angelats, E.; de la Sierra, A.; Sierra, C.; Parati, G.; Mancia, G.; Coca, A. Blood pressure variability and silent cerebral damage in essential hypertension. Am. J. Hypertens. 2004, 17, 696-700. [CrossRef] [PubMed]

46. Jaubert, M.P.; Jin, Z.; Russo, C.; Schwartz, J.E.; Homma, S.; Elkind, M.S.V.; Rundek, T.; Sacco, R.L.; Di Tullio, M.R. Alcohol consumption and ambulatory blood pressure: A community-based study in an elderly cohort. Am. J. Hypertens. 2014, 27, 688-694. [CrossRef] [PubMed] 
47. Sierksma, A.; Lebrun, C.E.; van der Schouw, Y.T.; Grobbee, D.E.; Lamberts, S.W.J.; Hendriks, H.F.J.; Bots, M.L. Alcohol consumption in relation to aortic stiffness and aortic wave reflections: A cross-sectional study in healthy postmenopausal women. Arterioscler Thromb Vasc. Biol. 2004, 24, 342-348. [CrossRef] [PubMed]

48. Mukamal, K.J.; Chen, C.M.; Rao, S.R.; Breslow, R.A. Alcohol consumption and cardiovascular mortality among U.S. adults, 1987 to 2002. J. Am. Coll. Cardiol. 2010, 55, 1328-1335. [CrossRef]

(C) 2020 by the authors. Licensee MDPI, Basel, Switzerland. This article is an open access article distributed under the terms and conditions of the Creative Commons Attribution (CC BY) license (http://creativecommons.org/licenses/by/4.0/). 